\title{
Influence of Zn species in HZSM-5 on ethylene aromatization
}

\author{
Xuchuan Chen a,b, Mei Dong a,\#, Xianjun Niu a,b, Kai Wang a,b, Gang Chen a,b, Weibin Fan a,*, \\ Jianguo Wang a, Zhangfeng Qin a \\ a State Key Laboratory of Coal Conversion, Institute of Coal Chemistry, Chinese Academy of Sciences, Taiyuan 030001, Shanxi China \\ b University of Chinese Academy of Sciences, Beijing 100049, China
}

\section{A R T I C L E I N F O}

\section{Article history:}

Received 27 November 2014

Accepted 9 January 2015

Published 20 June 2015

Keywords:

Ethylene

Aromatization

Zn species

HZSM-5

Dehydrogenation

\begin{abstract}
A B S T R A C T
Zn-containing HZSM-5 zeolites with different Zn contents were prepared by ion exchange and physically mixing methods, and were characterized by X-ray diffraction, scanning electron microscope, $\mathrm{N}_{2}$ adsorption-desorption, $\mathrm{NH}_{3}$ temperature programmed desorption, pyridine adsorption infrared spectroscopy, ultraviolet-visible diffuse reflectance spectroscopy and X-ray photoelectron spectroscopy. Zn species introduced into HZSM-5 were identified as ZnO crystals, ZnO clusters in the zeolite channel and $\mathrm{Zn}(\mathrm{OH})^{+}$species formed from a solid state reaction between dispersed $\mathrm{ZnO}$ and the protons in the zeolite. The preparation method has a significant influence on the distribution of the Zn species. The catalytic behavior of Zn-containing HZSM-5 with different Zn contents showed that the $\mathrm{Zn}(\mathrm{OH})^{+}$and $\mathrm{ZnO}$ species were responsible for aromatic formation from ethylene.
\end{abstract} (C) 2015, Dalian Institute of Chemical Physics, Chinese Academy of Sciences. Published by Elsevier B.V. All rights reserved.

\section{Introduction}

Aromatic hydrocarbons are the foundation of organic chemicals, and are widely used in the production of drugs, fuel, and polymers. Aromatic hydrocarbons are mainly obtained from oil and coal tar industrially by catalytic reforming and aromatic extraction processes. With the growing shortage of oil resources, researchers are developing new routes for aromatic production. The aromatization of the dry gas (methane, ethane, ethylene) from catalytic cracking and liquid petroleum gases (propane, propylene, and $\mathrm{C}_{4}$ hydrocarbons) have received wide attention [1-4]. However, research on ethylene aromatization is limited $[5,6]$.

In the aromatization reaction, Zn-containing HZSM-5 catalysts are widely used because of their good dehydrogenation performance due to the presence of $\mathrm{Zn}$ species and the high selectivity to aromatics due to the proper acid distribution and unique pore structure of HZSM-5 [7-13]. The state and role of the $\mathrm{Zn}$ species in HZSM-5 for the aromatization reaction are still unclear. Berndt et al. [14] used temperature programmed surface reaction with $\mathrm{CO}$ as the probe molecule (TPSR/CO) to distinguish between $\mathrm{Zn}^{2+}$ ions and oxygenated $\mathrm{Zn}$ species. Kolyagin et al. [15] studied Zn/HZSM-5 prepared by impregnation, and concluded that there were three kinds of $\mathrm{Zn}$ species as small $\mathrm{ZnO}$ crystals, $\mathrm{ZnO}$ clusters and $\mathrm{Zn}$ ions $\left(\mathrm{Zn}^{2+}\right.$ and $\left.\mathrm{Zn}(\mathrm{OH})^{+}\right)$. Biscardi et al. [16] found that the $\mathrm{Zn}(\mathrm{OH})^{+}$species was unstable and reacted with acidic groups $(-\mathrm{OH})$ to form other $\mathrm{Zn}$ species. Yakerson et al. [17] obtained similar results using pyridine adsorption, and suggested that one $\mathrm{Zn}$ cation could substitute two protons of an $\mathrm{OH}$ group and reacted with two Al sites. Most of the research was focused on $\mathrm{Zn}$ ions, while few researchers paid attention on the $\mathrm{ZnO}$ species. In this paper, $\mathrm{ZnO}$ was in-

\footnotetext{
* Corresponding author. Tel: +86-351-4199009; Fax:+86-351-4041153; E-mail: fanwb@sxicc.ac.cn

\# Corresponding author. Tel: +86-351-4046736; Fax: +86-351-4041153; E-mail: mdong@ sxicc.ac.cn

This work was supported by the National Basic Research Program of China (973 Program, 2011CB201400), the National Natural Science Foundation of China (21273263, 21273264, 21227002), and the Natural Science Foundation of Shanxi Province of China (2012011005-2, 2013021007-3). DOI: 10.1016/S1872-2067(14)60289-8 | http://www.sciencedirect.com/science/journal/18722067 | Chin. J. Catal., Vol. 36, No. 6, June 2015
} 
troduced into HZSM-5 zeolite by a physically mixing method and compared with the $\mathrm{Zn}$ species introduced by ion exchange with respect to the acidity, pore structure, state of $\mathrm{Zn}$, and catalytic performance in ethylene aromatization. It was concluded that the $\mathrm{ZnO}$ species had both a dehydrogenation and hydrogenation function, and it influenced the reaction by modulating the amount of Brönsted acid sites.

\section{Experimental}

\subsection{Catalyst preparation}

ZSM-5 was synthesized from silica sol ( $40 \mathrm{wt} \% \mathrm{SiO}_{2}, 0.4$ $\left.w t \% \mathrm{Na}_{2} \mathrm{O}\right), \mathrm{NaAlO}_{2}\left(\mathrm{Al}_{2} \mathrm{O}_{3}, 41.0 \mathrm{wt} \%\right)$, tetrapropyl ammonium hydroxide (TPAOH, $48.7 \mathrm{wt} \%$ in aqueous solution) and deionized water with the molar composition of $\mathrm{SiO}_{2}: 0.014 \mathrm{Al}_{2} \mathrm{O}_{3}$ : $0.033 \mathrm{NaO}_{2}: 0.15 \mathrm{TPAOH}: 30 \mathrm{H}_{2} \mathrm{O}$. In the synthesis procedure, 0.2 $w t \%$ silicalite- 1 seed prepared by following the procedure described in Ref. [18] was added to the above gel to get samples with a uniform particle size. The crystallization was conducted at $170{ }^{\circ} \mathrm{C}$ for $2 \mathrm{~d}$ in a teflon-lined stainless steel autoclave under rotation $(15 \mathrm{r} / \mathrm{min})$. The solid products were recovered by centrifugation, washed, dried at $100{ }^{\circ} \mathrm{C}$ overnight, and calcined at $560{ }^{\circ} \mathrm{C}$ for $10 \mathrm{~h}$ in air to remove the template. The HZSM-5 zeolite in the hydrogen form was obtained by ion exchange with aqueous $\mathrm{NH}_{4} \mathrm{NO}_{3}$ solution $(1 \mathrm{~mol} / \mathrm{L}, m$ (liquid) $/ m$ (solid) $=$ 40 ) at $80^{\circ} \mathrm{C}$ for $4 \mathrm{~h}$ and subsequent calcination at $560{ }^{\circ} \mathrm{C}$ for 10 $h$ in air.

Zn(IE)/HZSM-5 samples prepared by ion exchange (IE) were obtained by stirring $\mathrm{NH}_{4}-\mathrm{ZSM}-5$ in $\mathrm{Zn}\left(\mathrm{NO}_{3}\right)_{2}$ solution $(0.03 \mathrm{~mol} / \mathrm{L}, m$ (liquid) $/ m$ (solid $)=60)$ at $80{ }^{\circ} \mathrm{C}$, followed by drying at $100{ }^{\circ} \mathrm{C}$ for $6 \mathrm{~h}$ and calcination at $560{ }^{\circ} \mathrm{C}$ for $5 \mathrm{~h}$. By controlling the exchange time, four $\mathrm{Zn}(\mathrm{IE}) / \mathrm{HZSM}-5$ samples were obtained and denoted as IE-1, IE-2, IE-3, and IE-4, with Zn content of $0.43 \%, 0.74 \%, 1.22 \%$, and $1.42 \%$, respectively, as determined by inductively coupled plasma atomic emission spectroscopy (ICP-AES).

Zn(PM)/HZSM-5 samples were prepared by mechanically grinding a physical mixture (PM) of HZSM-5 and ZnO powder and calcination at $560{ }^{\circ} \mathrm{C}$ for $10 \mathrm{~h}$. Five $\mathrm{Zn}(\mathrm{PM}) / \mathrm{HZSM}-5$ samples were acquired and denoted as PM-1, PM-2, PM-3, PM-4, and PM-5, with $\mathrm{Zn}$ content of $0.2 \%, 0.43 \%, 0.74 \%, 1.22 \%$, and $2.0 \%$, respectively.

\subsection{Catalyst characterization}

X-ray diffraction (XRD) patterns were recorded on a Rigaku MiniFlex II desktop X-ray diffractometer $(\lambda=154.06 \mathrm{pm}, 30 \mathrm{kV}$, $15 \mathrm{~mA}$ ) using $\mathrm{Cu} K_{\alpha}$ radiation. The BET surface area was calculated from the $\mathrm{N}_{2}$ adsorption-desorption isotherm measured at $-195.8{ }^{\circ} \mathrm{C}$ on a Micromeritics TriStar II. Prior to the measurement, the sample was outgassed at $300{ }^{\circ} \mathrm{C}$ for $8 \mathrm{~h}$. The actual amounts of $\mathrm{Si}, \mathrm{Al}$ and $\mathrm{Zn}$ in the sample were determined by ICP-AES (Autoscan16, TJA). The crystal morphology and size were obtained with a field emission scanning electron microscope (FESEM, JSM 7001-F, JEOL, Japan). The acidity was measured by the temperature programmed desorption of $\mathrm{NH}_{3}$
( $\mathrm{NH}_{3}$-TPD) with a Micromeritics AutoChem II 2920 chemisorption analyzer equipped with a thermal conductivity detector (TCD). Approximately $100 \mathrm{mg}$ of zeolite sample was pretreated in $\mathrm{Ar}$ stream (30 ml/min) at $550{ }^{\circ} \mathrm{C}$ for $2 \mathrm{~h}$ and then cooled down to $120{ }^{\circ} \mathrm{C}$. The adsorption of $\mathrm{NH}_{3}$ on the zeolite sample was achieved by introducing gaseous $\mathrm{NH}_{3}$ (5 vol\% in $\mathrm{Ar}, 30$ $\mathrm{ml} / \mathrm{min}$ ) into the sample tube for $30 \mathrm{~min}$. The catalyst was flushed with $\operatorname{Ar}(30 \mathrm{ml} / \mathrm{min})$ at $120^{\circ} \mathrm{C}$ for $2 \mathrm{~h}$ to remove physisorbed $\mathrm{NH}_{3}$ from the catalyst surface. The TPD profile was recorded from 120 to $550{ }^{\circ} \mathrm{C}$ at a heating rate of $10{ }^{\circ} \mathrm{C} / \mathrm{min}$. The quantity of strong, medium and weak acid sites was measured by the amount of $\mathrm{NH}_{3}$ desorbed at 300-550, 200-300 and 100-200 ${ }^{\circ} \mathrm{C}$, respectively. Fourier transform infrared (FT-IR) spectra were measured on a Bruker Tensor 27 FT-IR spectrometer. The zeolite sample was first pressed into a self-supported wafer. Prior to the measurement, the sample cell was evacuated to $0.01 \mathrm{~Pa}$ at $450{ }^{\circ} \mathrm{C}$ for $2 \mathrm{~h}$. The IR spectra were then recorded at room temperature. To get the FT-IR spectra for pyridine adsorption (Py-IR), pyridine vapor was introduced into the cell at room temperature for $1 \mathrm{~h}$. The spectra were then recorded after evacuation at $150{ }^{\circ} \mathrm{C}$ for $1 \mathrm{~h}$. The concentrations of the different acid sites were calculated by following the procedures reported by Madeira and coworkers [19]. X-ray photoelectron spectroscopy (XPS) was recorded on an AXIS ULTRA DLD spectrometer with an $\mathrm{Al} K_{\alpha}$ radiation source $(h v=1486.6$ $\mathrm{eV})$. $\mathrm{Zn} 2 p$ spectra were measured in the range of 1013-1063 $\mathrm{eV}$.

\subsection{Catalyst tests}

The catalytic tests were performed in a continuous flow fixed bed reactor with an inner diameter of $10 \mathrm{~mm}$. The catalyst samples were pressed into wafers and then crushed and sieved to 20-40 mesh. In a typical run, $1.0 \mathrm{~g}$ of the catalyst was loaded and then activated at $480{ }^{\circ} \mathrm{C}$ for $0.5 \mathrm{~h}$ under $\mathrm{N}_{2}(30 \mathrm{ml} / \mathrm{min})$ before starting reaction. After that, ethylene was pumped into the reactor with a weight hourly space velocity (WHSV) of 0.9 $\mathrm{h}^{-1}$. The reaction was carried out at $480{ }^{\circ} \mathrm{C}$ and $0.1 \mathrm{MPa}$. The gas and liquid products were separated in a cold trap. The gas products were online analyzed by an Aglient 7890A gas chromatograph equipped with one TCD and two FID detectors and two capillary columns $\mathrm{J}^{*} \mathrm{~W} 127-7031,30 \mathrm{~m} \times 530 \mu \mathrm{m} \times 0.25$ $\mu \mathrm{m}$; Aglient 19095P-S25, $50 \mathrm{~m} \times 530 \mu \mathrm{m} \times 15 \mu \mathrm{m})$. The liquid organic phase was analyzed by another Aglient 7890A gas chromatograph equipped with a FID detector and a capillary column (Aglient 19091S-001, $50 \mathrm{~m} \times 200 \mu \mathrm{m} \times 0.5 \mu \mathrm{m}$ ).

\section{Results and discussion}

\subsection{Textural properties}

The textural properties of HZSM-5 and the Zn-containing HZSM-5 zeolites are summarized in Table 1. For the Zn-containing samples, the surface Zn contents determined by XPS were consistent with the bulk values measured by ICP-AES at low Zn loadings, but more $\mathrm{Zn}$ species was concentrated on the zeolite surface when the $\mathrm{Zn}$ content was higher than 0.74 
Table 1

Textural properties of HZSM-5 and Zn-containing HZSM-5 zeolites.

\begin{tabular}{|c|c|c|c|c|c|c|}
\hline \multirow{2}{*}{ Sample } & \multirow{2}{*}{$\begin{array}{c}\text { Crystallinity } \\
(\%)\end{array}$} & \multicolumn{2}{|c|}{ Zn content } & \multirow{2}{*}{$\begin{array}{c}A_{\mathrm{BET}} \\
\left(\mathrm{m}^{2} / \mathrm{g}\right)\end{array}$} & \multirow{2}{*}{$\begin{array}{c}V_{\text {micro }} \\
\left(\mathrm{cm}^{3} / \mathrm{g}\right)\end{array}$} & \multirow{2}{*}{$\begin{array}{c}V_{\text {meso }} \\
\left(\mathrm{cm}^{3} / \mathrm{g}\right)\end{array}$} \\
\hline & & ICP & XPS & & & \\
\hline HZSM-5 & 100 & 0 & 0 & 354 & 0.120 & 0.096 \\
\hline IE-1 & 98.7 & 0.43 & 0.33 & 340 & 0.110 & 0.115 \\
\hline IE-2 & 98.4 & 0.74 & 0.80 & 345 & 0.111 & 0.115 \\
\hline IE-3 & 99.2 & 1.22 & 1.61 & 340 & 0.111 & 0.112 \\
\hline IE-4 & 95.7 & 1.42 & 2.24 & 341 & 0.110 & 0.121 \\
\hline PM-1 & 95.3 & 0.20 & 0.22 & 346 & 0.111 & 0.122 \\
\hline PM-2 & 96.7 & 0.43 & 0.93 & 339 & 0.110 & 0.115 \\
\hline PM-3 & 94.1 & 0.74 & 1.17 & 343 & 0.111 & 0.120 \\
\hline PM-4 & 96.2 & 1.22 & 1.82 & 336 & 0.109 & 0.114 \\
\hline PM-5 & 87.3 & 2.00 & 3.70 & 335 & 0.108 & 0.118 \\
\hline
\end{tabular}

Note: $A_{\text {BET, }}$ BET surface area; $V_{\text {micro, }}$ micropore volume determined by $t$-plot; $V_{\text {meso }}$, mesopore volume determined by $V_{\text {total }}-V_{\text {micro; }}$ Crystallinity estimated by comparing the total XRD peak area of the zeolite sample in the range of $2 \theta$ from $22^{\circ}$ to $25^{\circ}$ with that of the parent HZSM- 5 having the strongest diffraction intensity.

$w t \%$ on the samples prepared by ion exchange and $0.43 \mathrm{wt} \%$ on the samples prepared by physically mixing. At the same $\mathrm{Zn}$ amount, the surface Zn content on Zn(PM)/HZSM-5 was higher than that on Zn(IE)/HZSM-5, suggesting that more Zn was admitted into the zeolite channels when $\mathrm{Zn}$ was introduced by ion exchange.

The XRD patterns of the parent HZSM-5 and Zn-containing HZSM-5 samples are illustrated in Fig. 1. All the samples exhibited the same characteristic diffraction peaks of the MFI structure, suggesting that the presence of Zn species has little influence on the framework structure of the parent HZSM-5. However, a slight decrease of the crystallinity with the introduction of $\mathrm{Zn}$ can be found in Table 1, which was ascribed to the mixing of the Zn species with HZSM-5 zeolite rather than a detriment of the crystalline framework. Furthermore, the diffraction peaks for $\mathrm{ZnO}$ at $36.3^{\circ}$ and $31.8^{\circ}$ can be seen on $\mathrm{Zn}(\mathrm{PM}) / \mathrm{HZSM}-5$ samples with $\mathrm{Zn}$ contents higher than 0.74 $w \mathrm{t} \%$, which suggested the presence of crystalline $\mathrm{ZnO}$ in the samples prepared by the physically mixing method.

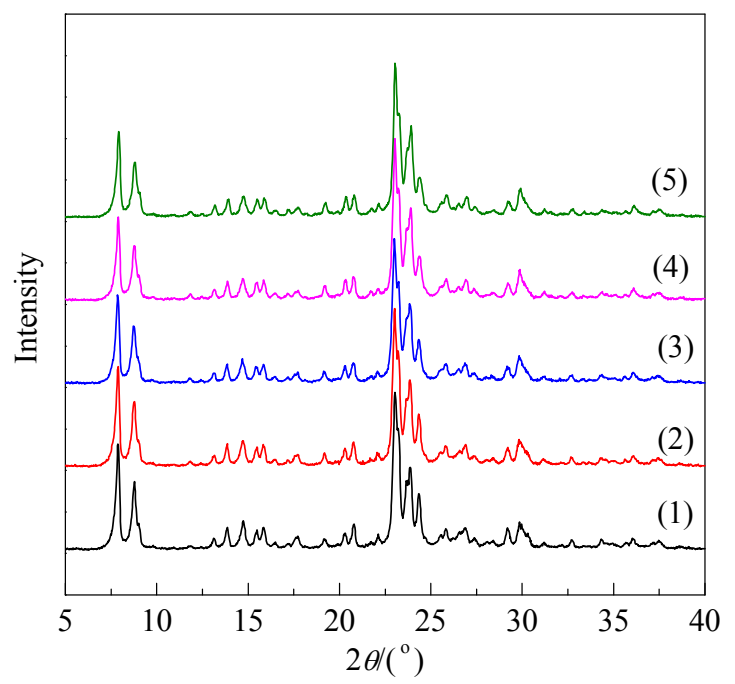

Figure 2 shows the SEM images of HZSM-5 and the Zn-containing HZSM-5. The introduction of $\mathrm{Zn}$ by ion exchange and physically mixing has little effect on the particle size and morphology of the parent HZSM-5 with the particle size of 1 $\mu \mathrm{m}$. On the other hand, $\mathrm{ZnO}$ crystals with particle sizes of $100-$ $200 \mathrm{~nm}$ were observed in the SEM images of the Zn(PM)/HZSM-5 samples with high Zn contents, consistent with the XRD results.

The surface area and microporous volume of HZSM-5 decreased with the introduction of $\mathrm{Zn}$ species by both the ion exchange and physically mixing methods, as shown in Table 1. This suggested that the $\mathrm{Zn}$ species were located in the porous channels, which reduced the accessibility of the micropores of the zeolite. On the other hand, the mesoporous volumes of the Zn-containing HZSM-5 samples were much higher than the parent HZSM-5, which was related to the stacked nano-particles and inter-crystal voids. Ni et al. [20] found similar inter-crystal voids when synthesizing nano-sized $\mathrm{H}[\mathrm{Zn}$, Al]ZSM-5, and suggested that these inter-crystal voids were similar to intra-crystalline mesopores, and that they provided enough space to store coke to prevent the entrance of the micropores from being blocked, which would effectively prolong the lifetime in the methanol-to-aromatic (MTA) reaction.

\subsection{Acid properties}

The concentration and distribution of the acid sites in HZSM-5 and Zn-containing HZSM-5 are summarized in Table 2. Generally, the $\mathrm{NH}_{3}$-TPD profile of HZSM-5 zeolite has two desorption peaks, i.e., a high temperature peak (above $300{ }^{\circ} \mathrm{C}$ ) and low temperature peak (below $200{ }^{\circ} \mathrm{C}$ ), which were assigned to $\mathrm{NH}_{3}$ adsorbed on strong and weak acid sites, respectively. In this work, the distribution of the acid sites was determined by integrating the $\mathrm{NH}_{3}$-TPD profiles in the different temperature intervals, as listed in Table 2. The quantities of strong, medium, and weak acid sites were measured by the amounts of $\mathrm{NH}_{3}$ desorbed at 300-550, 200-300, and 120-200 ${ }^{\circ} \mathrm{C}$, respectively. With the introduction of $\mathrm{Zn}$ species and the

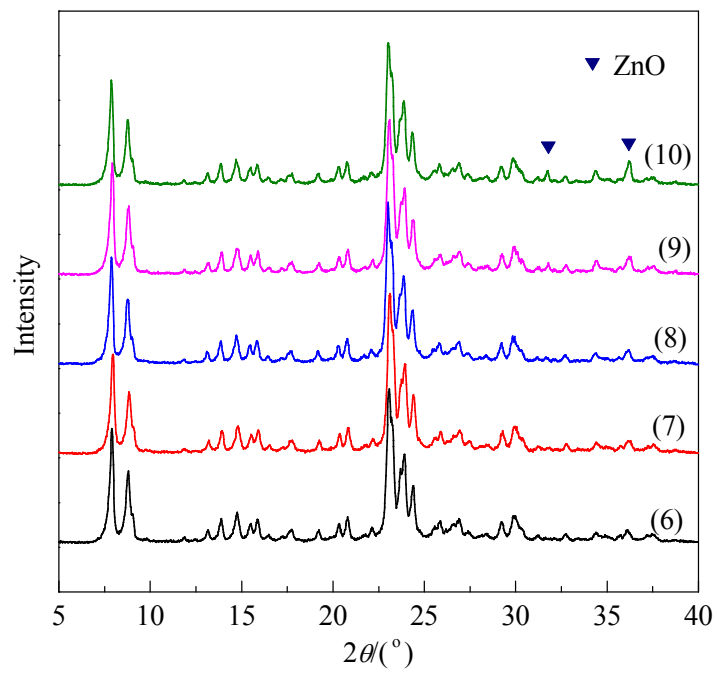

Fig. 1. XRD patterns of HZSM-5, Zn(IE)/HZSM-5 and Zn(PM)/HZSM-5 with different Zn contents. (1) HZSM-5; (2) IE-1; (3) IE-2; (4) IE-3; (5) IE-4; (6) PM-1; (7) PM-2; (8) PM-3; (9) PM-4; (10) PM-5. 

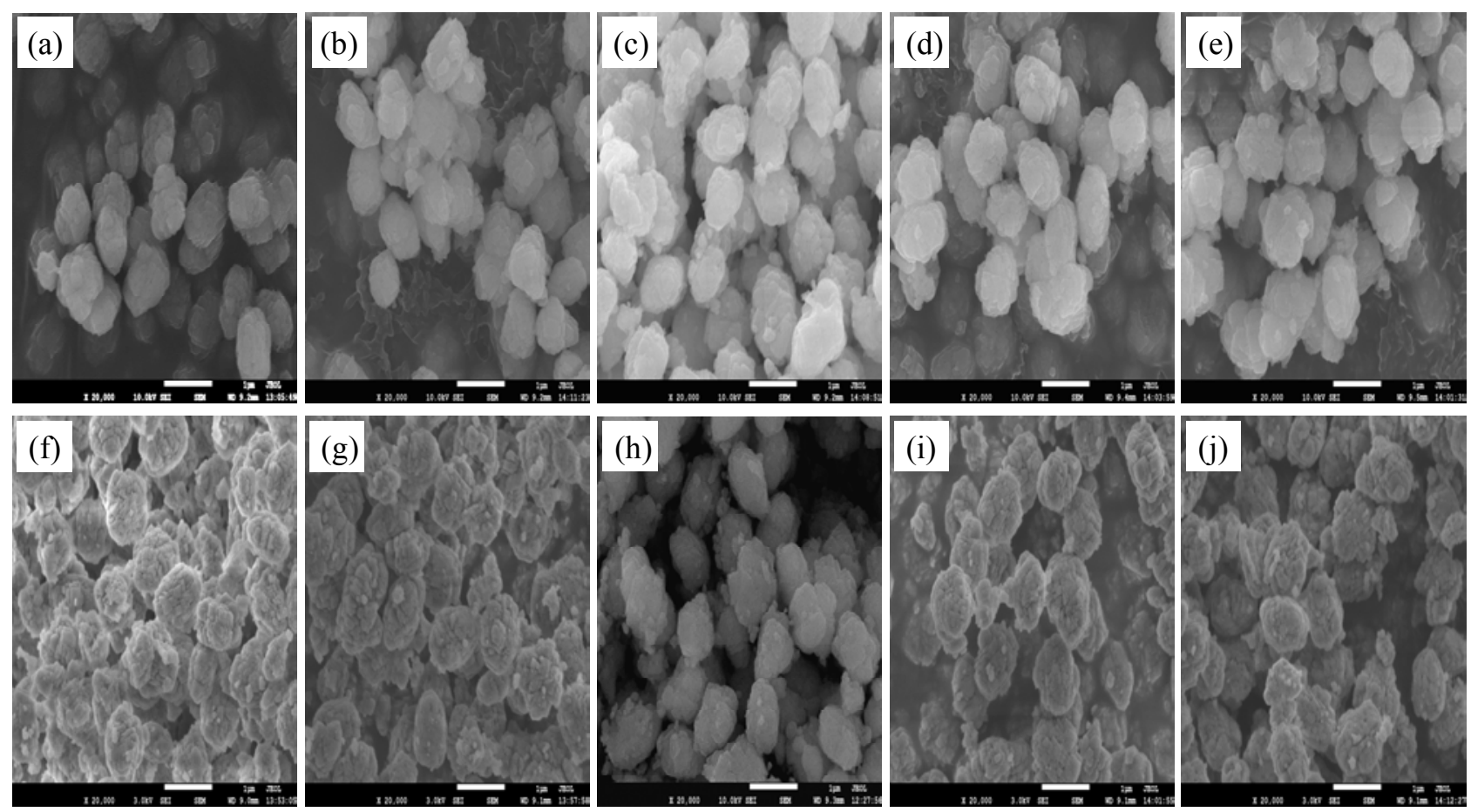

Fig. 2. SEM images of HZSM-5, Zn(IE)/HZSM-5 and Zn(PM)/HZSM-5 with different Zn contents. (a) HZSM-5; (b) IE-1; (c) IE-2; (d) IE-3; (e) IE-4; (f) PM-1; (g) PM-2; (h) PM-3; (i) PM-4; (j) PM-5.

Table 2

Acidic properties of HZSM-5 and Zn-containing HZSM-5 zeolites.

\begin{tabular}{|c|c|c|c|c|c|c|c|}
\hline \multirow{2}{*}{ Sample } & \multicolumn{4}{|c|}{ Acidity by strength ${ }^{\text {a }}(\mathrm{mmol} / \mathrm{g})$} & \multicolumn{3}{|c|}{ Acidity by type ${ }^{b}$} \\
\hline & Strong & Medium & Weak & Total & Brönsted $(\mu \mathrm{mol} / \mathrm{g})$ & Lewis $(\mu \mathrm{mol} / \mathrm{g})$ & $\mathrm{B} / \mathrm{L}^{\mathrm{c}}$ \\
\hline HZSM-5 & 0.410 & 0 & 0.330 & 0.74 & 265.61 & 96.69 & 2.75 \\
\hline IE-1 & 0.288 & 0.201 & 0.171 & 0.66 & 208.60 & 163.89 & 1.27 \\
\hline IE-2 & 0.329 & 0.255 & 0.146 & 0.75 & 200.73 & 255.30 & 0.79 \\
\hline IE-3 & 0.358 & 0.231 & 0.141 & 0.76 & 151.63 & 361.37 & 0.42 \\
\hline IE-4 & 0.320 & 0.263 & 0.138 & 0.73 & 107.05 & 446.95 & 0.32 \\
\hline PM-1 & 0.253 & 0.091 & 0.226 & 0.57 & 218.14 & 90.36 & 2.41 \\
\hline PM-2 & 0.267 & 0.103 & 0.220 & 0.59 & 201.05 & 166.68 & 1.21 \\
\hline PM-3 & 0.278 & 0.108 & 0.182 & 0.57 & 138.62 & 200.95 & 0.69 \\
\hline PM-4 & 0.259 & 0.123 & 0.168 & 0.55 & 123.57 & 204.36 & 0.60 \\
\hline PM-5 & 0.262 & 0.128 & 0.142 & 0.53 & 91.70 & 213.42 & 0.43 \\
\hline
\end{tabular}

a Density of acid sites determined by $\mathrm{NH}_{3}-\mathrm{TPD}$ (strong, $\mathrm{NH}_{3}$ desorbed at $300-550{ }^{\circ} \mathrm{C}$; medium, $\mathrm{NH}_{3}$ desorbed at $200-300{ }^{\circ} \mathrm{C}$; weak, $\mathrm{NH}_{3}$ desorbed at $120-200^{\circ} \mathrm{C}$;

b Density of acid sites determined by Py-IR;

c Brönsted/Lewis ratio determined by Py-IR.

change of Zn amounts in HZSM-5, the distribution of the acid sites and the acidic strength changed significantly (Table 2). It is interesting to note that with the introduction of $\mathrm{Zn}$ species, new acid sites of medium strength appeared at the expense of weak and strong acid sites. The amount of the medium acid sites increased with the $\mathrm{Zn}$ content, suggesting that this type of acid site can be ascribed to an interaction between the Zn species and intrinsic acid sites in the parent HZSM- 5 zeolite. On the other hand, the method of $\mathrm{Zn}$ introduction has a significant influence on the acid amount. The presence of $\mathrm{Zn}$ species introduced by ion exchange has little influence on the acid quantity as shown in Table 2, while the acid amount of the $\mathrm{Zn}(\mathrm{PM}) / \mathrm{HZSM}-5$ samples was reduced considerably with increased $\mathrm{Zn}$ content, which may be ascribed to that the presence of $\mathrm{ZnO}$ crystals covered the acid sites.

Chemisorbed pyridine on Brönsted acid sites and Lewis acid sites are characteristic by Py-IR absorption bands at 1545 and $1454 \mathrm{~cm}^{-1}$ (Fig. 3), respectively. The different distribution of the Lewis and Brönsted acid sites with the introduction of $\mathrm{Zn}$ by the different methods pointed to the generation of new Lewis acid sites with the consumption of Brönsted acid sites (Table 2). With the increase of $\mathrm{Zn}$ content in the samples obtained by the different methods, the amount of Brönsted acid sites decreased and the amount of Lewis acid sites increased. As a consequence, the decrease of the $\mathrm{B} / \mathrm{L}$ ratio with the increase of $\mathrm{Zn}$ content confirmed that an interaction between the Brönsted acid sites and $\mathrm{Zn}$ ions occurred. On comparing the Zn-containing samples prepared by the different methods, it 

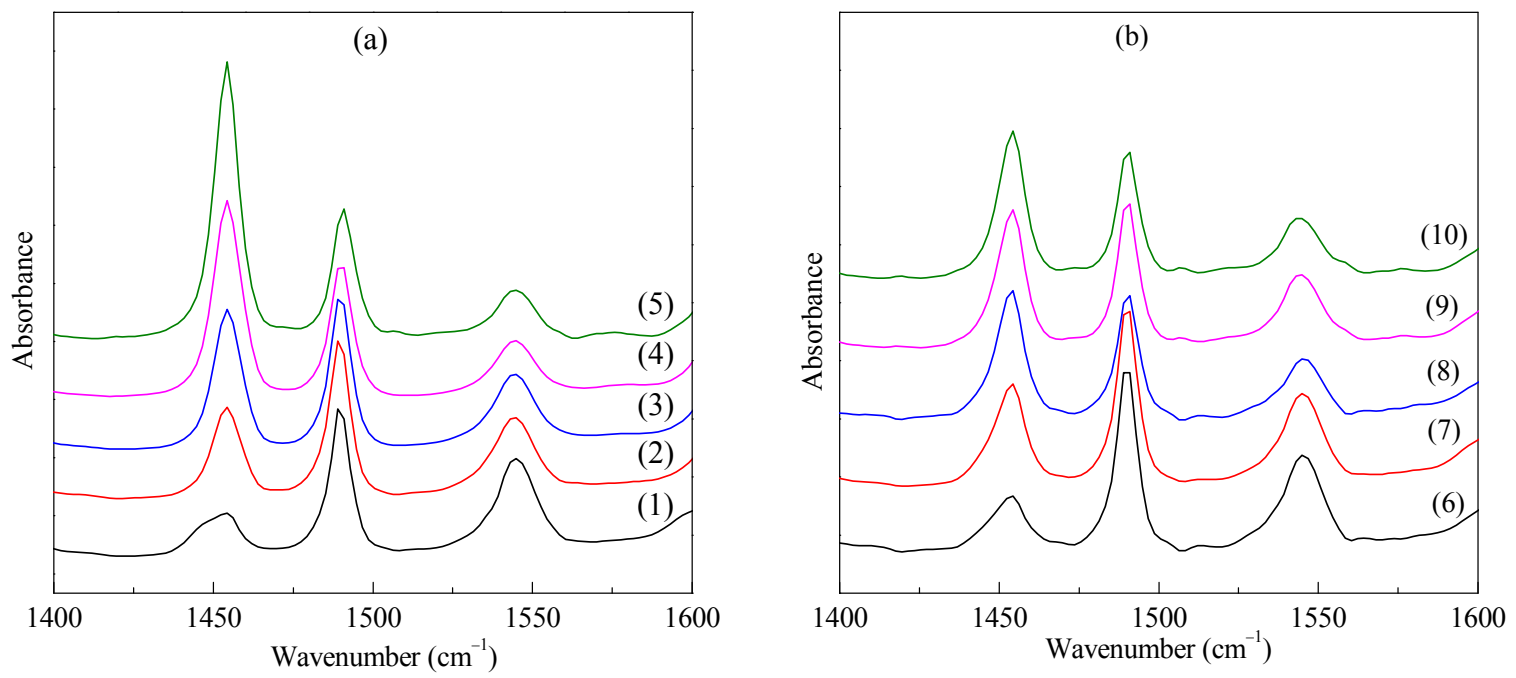

Fig. 3. Py-IR spectra of Zn-containing HZSM-5 zeolites prepared by ion exchange (a) and physically mixing (b). (1) HZSM-5; (2) IE-1; (3) IE-2; (4) IE-3; (5) IE-4; (6) PM-1; (7) PM-2; (8) PM-3; (9) PM-4; (10) PM-5.

was found that a much higher $\mathrm{B} / \mathrm{L}$ ratio was obtained on the Zn(PM)/HZSM-5 zeolite obtained from physically mixing.

The FT-IR spectra in the $\mathrm{OH}$ stretching region (Fig. 4) suggested that HZSM-5 contained Brönsted acid groups (3610 $\mathrm{cm}^{-1}$ ) associated with the framework aluminum [Si(OH)Al], isolated external silanol groups $\left(3742 \mathrm{~cm}^{-1}\right)$, free internal silanol groups $\left(3728 \mathrm{~cm}^{-1}\right)$, and delocalized hydrogen-bonded groups $\left(3500 \mathrm{~cm}^{-1}\right)$ of lattice defects. On the samples $\mathrm{Zn}$ (IE)/HZSM-5 prepared by ion exchange, the introduction of $\mathrm{Zn}$ species has little effect on the $\mathrm{OH}$ groups associated with 3500 and $3742 \mathrm{~cm}^{-1}$, the silanol groups characteristic by 3728 $\mathrm{cm}^{-1}$ were decreased slightly, which was attributed to the interaction between the internal silanol groups and $\mathrm{Zn}(\mathrm{OH})^{+}$cations located in cationic positions of the zeolites [21], and the Brönsted acid groups $\left(3610 \mathrm{~cm}^{-1}\right)$ were decreased obviously, suggesting the consumption of zeolite protons by ion exchange with $\mathrm{Zn}^{2+}$. However, on the Zn(PM)/HZSM-5 samples prepared

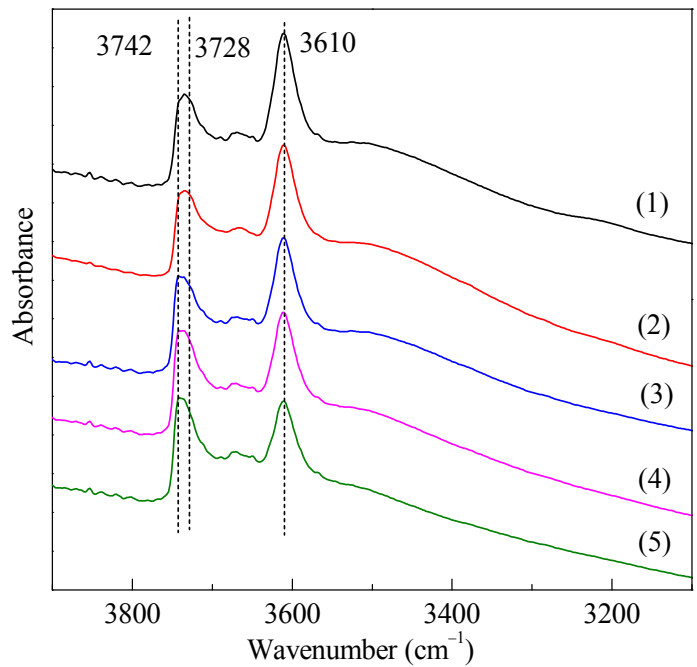

by physically mixing, the interaction between the $\mathrm{Zn}$ species with the hydroxyl groups differed from that of Zn(IE)/HZSM-5. Although a similar interaction between zeolite protons or internal silanol groups with Zn species was also found to a much smaller extent, a more pronounced change centered at 3666 $\mathrm{cm}^{-1}$ was observed. This was the result of the formation of external $\mathrm{Zn}-\mathrm{OH}$ groups on $\mathrm{ZnO}$ clusters [22]. This result confirmed that the $\mathrm{ZnO}$ species were mainly located on the surface of the zeolite for the Zn(PM)/HZSM-5 zeolites. Niu et al. [23] suggested that $\mathrm{Zn}$-Lewis acid species $\mathrm{Zn}(\mathrm{OH})^{+}$was dominant in the $\mathrm{Zn}$ (IE)/HZSM-5 zeolite, and ZnO species was the main species on Zn-containing samples prepared by the physically mixing method.

\subsection{State of Zn in HZSM-5}

Figure 5(a) and Figure 5(b) depict the UV-Vis DRS spectra of

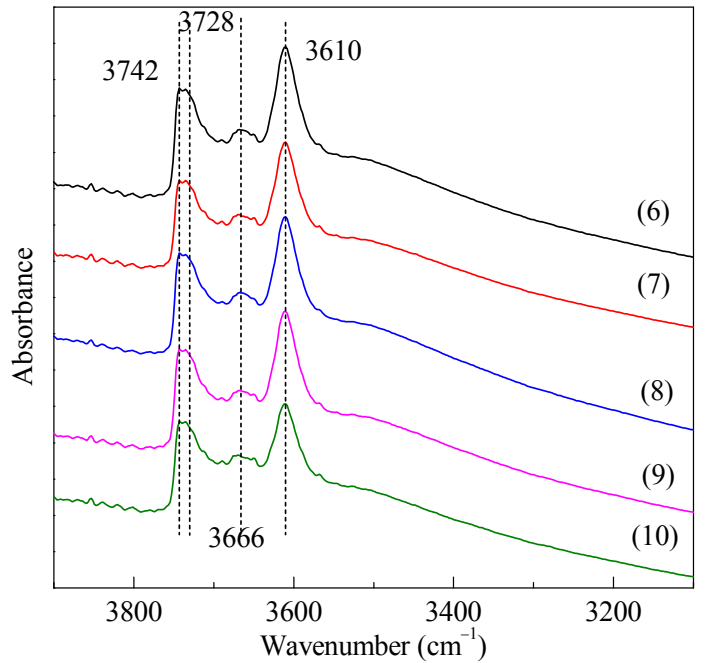

Fig. 4. FT-IR spectra of OH groups on HZSM-5 and Zn-containing HZSM-5 zeolites. (1) HZSM-5; (2) IE-1; (3) IE-2; (4) IE-3; (5) IE-4; (6) PM-1; (7) PM-2 (8) PM-3; (9) PM-4; (10) PM-5. 

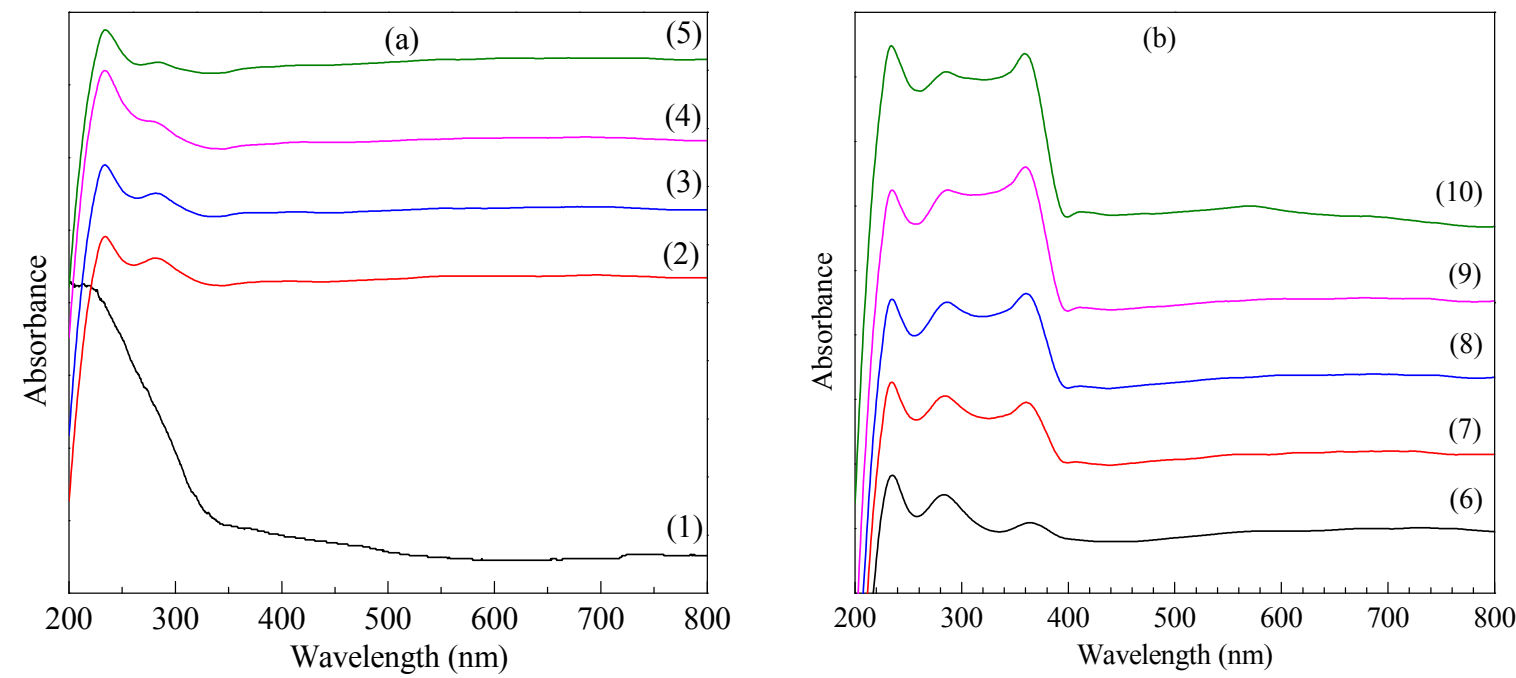

Fig. 5. UV-vis DRS spectra of Zn-containing HZSM-5 zeolites prepared by ion exchange (a) and physically mixing (b). (1) HZSM-5; (2) IE-1; (3) IE-2; (4 IE-3; (5) IE-4; (6) PM-1; (7) PM-2; (8) PM-3; (9) PM-4; (10) PM-5.

the Zn-containing HZSM-5 zeolites prepared by ion exchange and physically mixing, respectively. Three main absorption bands can be identified at 368, 275, and $220 \mathrm{~nm}$ in the $\mathrm{Zn}$-containing samples. The band at $368 \mathrm{~nm}$ corresponding to the band-gap width of macrocrystalline ZnO [24] appeared in the spectra of Zn(PM)/HZSM-5 prepared by physically mixing. The band at $275 \mathrm{~nm}$ attributed to $\mathrm{ZnO}$ cluster with a diameter of $10 \AA[25,26]$ was observed in all the Zn-containing samples. This indicated the presence of $\mathrm{ZnO}$ clusters located in the channels of these zeolites. On the other hand, the absorbance at 220 or $195 \mathrm{~nm}$ was evident in all the Zn-containing HZSM-5 zeolites, which was ascribed to the $\mathrm{Zn}$ species strongly interacting with the parent HZSM-5.

The Zn $2 p$ XPS spectra of the Zn-containing HZSM-5 zeolites are illustrated in Fig. 6. By curve fitting the Zn $2 p_{3 / 2}$ XPS spectra, two Zn species were discriminated in the Zn-containing HZSM-5 zeolites with binding energies at 1017.5 and 1022.8 $\mathrm{eV}$. As pure $\mathrm{ZnO}$ shows a peak at $1021.8 \mathrm{eV}$, it is reasonable to

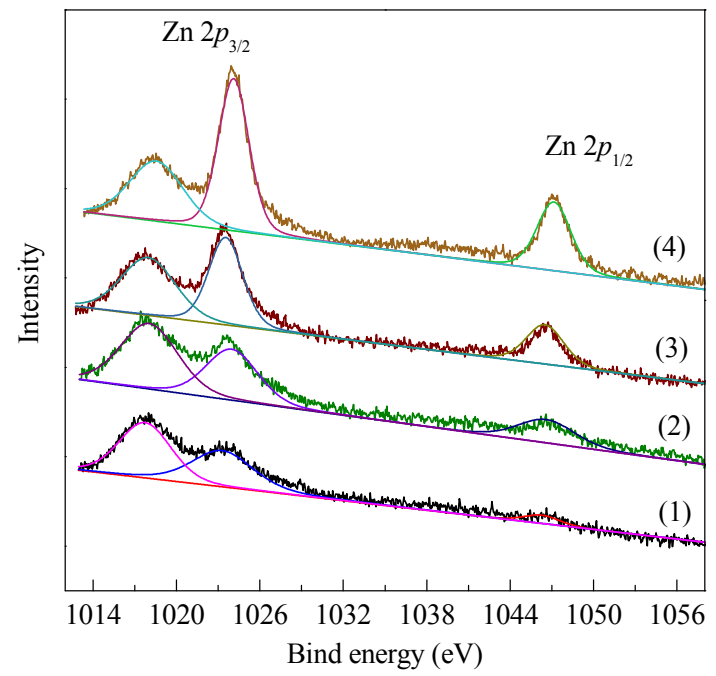

attribute the binding energy peak at $1022.8 \mathrm{eV}$ to $\mathrm{ZnO}$ species. On the other hand, the peak at $1017.50 \mathrm{eV}$ was attributed to another $\mathrm{Zn}^{2+}$ species that reacted with the zeolite framework [27]. Based on the evidence provided by UV-Vis DRS and XPS, it can be summarized that on the Zn(PM)/HZSM-5 samples prepared by physically mixing, the majority of the $\mathrm{Zn}$ species existed as $\mathrm{ZnO}$ crystals present on the surface of the zeolite, and ZnO clusters inside the channel. On the Zn(IE)/HZSM-5 samples, the proportion of $\mathrm{ZnO}$ species was suppressed considerably, and the Zn species were mainly inside the pore system and interacted with the acid sites by a much stronger interaction.

\subsection{Catalytic performance of Zn-containing HZSM-5 in ethylene aromatization}

The ethylene conversion and product distribution with the HZSM-5 catalyst and Zn-containing HZSM-5 catalysts are shown in Table 3. The introduction of Zn species into HZSM-5

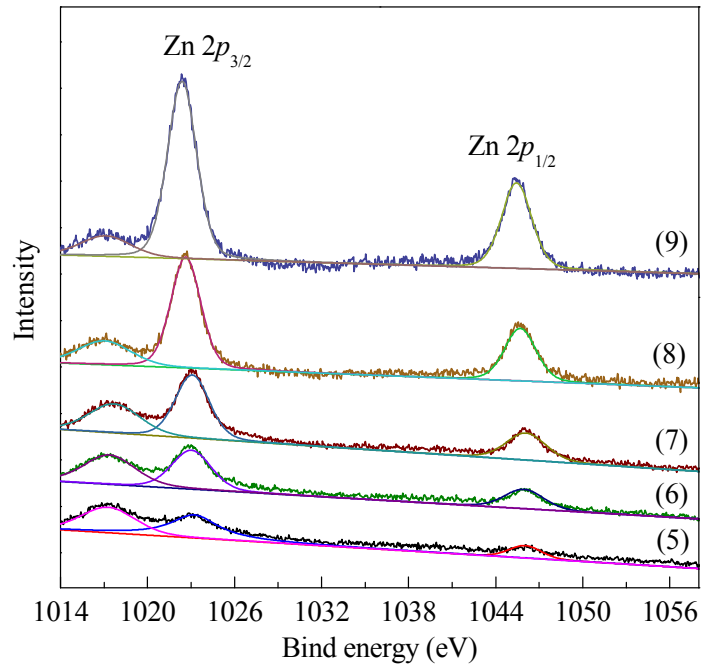

Fig. 6. XPS spectra of Zn $2 p$ of Zn-containing HZSM-5 zeolites. (1) IE-1; (2) IE-2; (3) IE-3; (4) IE-4; (5) PM-1; (6) PM-2; (7) PM-3; (8) PM-4; (9) PM-5. 
Table 3

Product selectivity of ethylene to aromatics over HZSM-5 and Zn-containing HZSM-5 zeolite catalysts.

\begin{tabular}{|c|c|c|c|c|c|c|c|c|}
\hline \multirow{2}{*}{ Catalyst } & \multirow{2}{*}{$\begin{array}{c}\mathrm{C}_{2} \mathrm{H}_{4} \\
\text { Conversion (\%) }\end{array}$} & \multicolumn{6}{|c|}{ Product selectivity (C\%) } & \multirow{2}{*}{$\begin{array}{c}\mathrm{H}_{2} \text { selectivity } \\
(\mathrm{mol} \%)\end{array}$} \\
\hline & & $\mathrm{CH}_{4}$ & $\mathrm{C}_{2} \mathrm{H}_{6}$ & $\mathrm{C}_{3}$ & $\mathrm{C}_{4}$ & $\mathrm{C}_{4+}{ }^{\mathrm{a}}$ & Aromatic & \\
\hline HZSM-5 & 97.63 & 2.37 & 7.65 & 31.29 & 13.28 & 3.12 & 38.94 & 12.49 \\
\hline IE-1 & 98.48 & 5.47 & 7.64 & 20.09 & 6.39 & 1.91 & 58.47 & 46.78 \\
\hline IE-2 & 98.88 & 6.98 & 10.69 & 13.28 & 4.35 & 1.47 & 63.21 & 48.21 \\
\hline IE-3 & 99.66 & 7.68 & 19.19 & 9.83 & 2.26 & 0.65 & 60.39 & 40.24 \\
\hline IE-4 & 99.72 & 7.24 & 21.80 & 9.00 & 2.05 & 0.94 & 58.95 & 36.85 \\
\hline PM-1 & 98.18 & 5.18 & 7.31 & 21.98 & 5.53 & 1.69 & 58.30 & 44.22 \\
\hline PM-2 & 98.92 & 7.12 & 9.79 & 13.84 & 3.80 & 1.33 & 64.11 & 48.59 \\
\hline PM-3 & 97.93 & 7.56 & 14.71 & 10.22 & 3.27 & 0.77 & 63.46 & 44.52 \\
\hline PM-4 & 99.77 & 7.34 & 21.45 & 8.72 & 1.73 & 1.73 & 59.03 & 36.15 \\
\hline PM-5 & 98.24 & 7.36 & 25.95 & 7.53 & 1.09 & 0.18 & 57.90 & 30.51 \\
\hline
\end{tabular}

Reaction conditions: $480^{\circ} \mathrm{C}, 0.1 \mathrm{MPa}, \mathrm{WHSV}$ of ethylene $0.9 \mathrm{~h}^{-1}$, data obtained at $18.5 \mathrm{~h}$.

${ }^{a} \mathrm{C}_{4+}$ : paraffin and olefins with carbon number higher than $4 .{ }^{\mathrm{b}}$ molar percent of $\mathrm{H}_{2}$ in the products.

zeolite by ion exchange or physically mixing improved the ethylene conversion and aromatic formation considerably. The variation of selectivity to aromatics, light hydrocarbons, and $\mathrm{H}_{2}$ with the increase of $\mathrm{Zn}$ content showed the same trend with the samples prepared by the different methods. On the catalysts with a low Zn loading, i.e. IE-1 and PM-1 with the lowest Zn loading of 0.43 and $0.2 \mathrm{wt} \%$, respectively, the presence of $\mathrm{Zn}$ promoted the production of aromatics and methane significantly, while the formation of propane, butane and heavier hydrocarbons was inhibited. It is interesting to note that the amount of increased aromatics was formed at the expense of $\mathrm{C}_{3}, \mathrm{C}_{4}$, and $\mathrm{C}_{4+}$ hydrocarbons on the IE- 1 and PM-1 catalysts as compared with the parent HZSM-5 catalyst. This means that $\mathrm{Zn}(\mathrm{OH})^{+}$species, the main $\mathrm{Zn}$ species in IE- 1 and PM-1 catalysts, accelerated the aromatization reaction by acting as dehydrogenation active sites for light alkanes, and thus promoted the production of aromatics. On the other hand, the decrease in Brönsted acid amount (Table 2) of the IE- 1 and PM-1 catalysts depressed the hydrogen transfer reaction, and contributed to the increased selectivity of aromatics as well.

When the $\mathrm{Zn}$ content was increased to 0.74 and $0.43 \mathrm{wt} \%$ on the IE-2 and PM-2 catalysts, respectively, the selectivity to aromatics reached a maximum value of $64 \%$, accompanied with the further suppressing of $\mathrm{C}_{3}, \mathrm{C}_{4}$, and $\mathrm{C}_{4+}$ hydrocarbons, and further promotion of the formation of methane and ethane. Hence, the dehydrogenation of $\mathrm{C}_{3+}$ hydrocarbons on the IE-2 and PM-2 catalysts resulted in the increase of aromatics and also methane and ethane. However, on the catalysts IE-3, IE-4, PM-4, and PM-5, which have high Zn contents, the selectivity to aromatics decreased, while ethane production increased significantly with the decrease of hydrogen, suggesting that the ethylene hydrogenation reaction became competitive on these catalysts. Because these catalysts have the same acid amount and acid site distribution, it is reasonable to deduce that $\mathrm{ZnO}$ species, which were dominant in these samples as characterized by XPS and were located in the channel or surface of the zeolite, were responsible for ethylene hydrogenation.

By comparing the IE-1 and PM-2 catalysts which have comparable Zn contents, it was seen that the PM-2 catalyst showed the better catalytic property in improving ethylene aromatization, accelerating the formation of methane and ethane, and suppressing the production of paraffins higher than $\mathrm{C}_{3}$. Considering the comparable amount of Brönsted acid sites (Table 2) with catalyst IE-1, the better aromatization capability of catalyst PM-2 may be ascribed to the different $\mathrm{Zn}$ species distribution. Although less $\mathrm{Zn}(\mathrm{OH})^{+}$existed on PM-2 than IE-1, the presence of $\mathrm{ZnO}$ crystals, suggested by the Py-IR, $\mathrm{NH}_{3}-\mathrm{TPD}$, UV-Vis DRS and XPS results, acted as active sites to promote the dehydrogenation of light alkanes and thus the formation of aromatics.

The above results showed that on Zn-containing HZSM-5 catalysts, acid sites benefited the oligomerization of ethylene to form $\left(\mathrm{CH}_{2}\right)_{n}(n=6,7,8)$ species (Reaction 1 in Scheme 1) [28], while $\mathrm{ZnO}$ species favor the hydrogenation reaction of ethylene

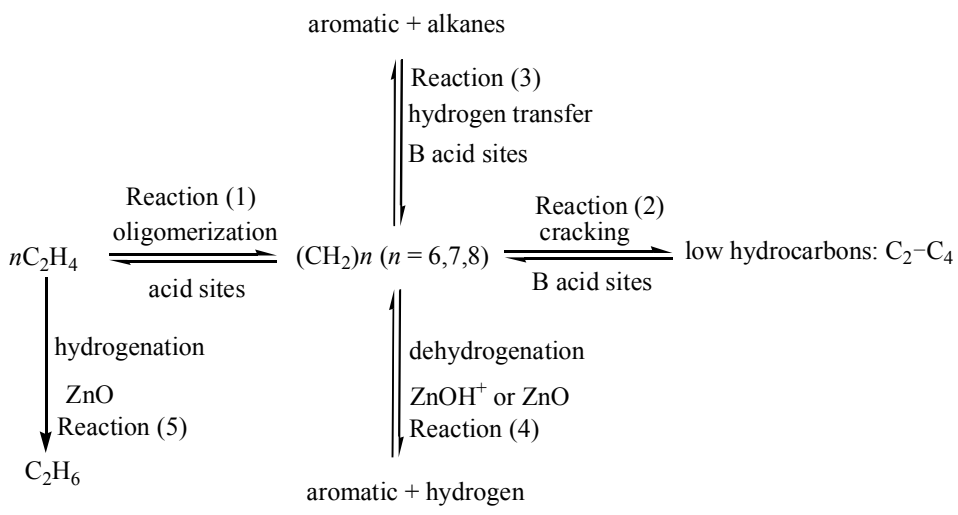

Scheme 1. Reaction routes for ethylene aromatization on Zn-containing HZSM-5. 
and dehydrogenation of light alkanes. In this process, the Brönsted acid sites also facilitate the cracking reaction (Reaction 2) of $\left(\mathrm{CH}_{2}\right)_{n}$ species to form $\mathrm{C}_{2}-\mathrm{C}_{4}$ hydrocarbons [29]. Aromatic hydrocarbons are then generated from $\left(\mathrm{CH}_{2}\right)_{n}$ species by two routes: in one, hydrogen transfer reaction occurs on Brönsted acid sites and aromatics and alkanes are produced (Reaction 3) [19,30], and in the other, dehydrogenation of light alkanes proceeds on the active sites of $\mathrm{Zn}(\mathrm{OH})^{+}$or $\mathrm{ZnO}$ and aromatics are formed accompanied with $\mathrm{H}_{2}$ production (Reaction 4). The latter route is more favorable for improving the aromatic selectivity and consuming more light alkanes without any consumption of olefins. Therefore, the aromatic production can be enhanced considerably with the synergy effect between the dehydrogenation species and Brönsted acid sites, which would have an optimal proportion to achieve the maximum selectivity to aromatics [29].

In summary, the introduction of Zn to HZSM-5 greatly improved the aromatic selectivity for ethylene aromatization by two routes. $\mathrm{Zn}(\mathrm{OH})^{+}$and $\mathrm{ZnO}$ species facilitate the dehydrogenation of $\left(\mathrm{CH}_{2}\right)_{n}$ and light alkanes, and thus promote the formation of aromatics. On the other hand, the interaction of $\mathrm{Zn}$ with the protons in the zeolite decreases the Brönsted acid sites, depresses the cracking and hydrogen transfer reactions of $\left(\mathrm{CH}_{2}\right)_{n}$ species, and hence decreases the selectivity to light alkanes. However, the presence of a large amount of $\mathrm{ZnO}$ crystals is adverse to the aromatization reaction from ethylene due to hydrogenation to form ethane.

\section{Conclusions}

The introduction of Zn species into HZSM-5 zeolite by ion exchange and physically mixing has significant influence on the textural properties, acidic properties and catalytic performance in ethylene aromatization. The $\mathrm{Zn}$ species were identified as $\mathrm{ZnO}$ crystals, $\mathrm{ZnO}$ clusters in the ZSM-5 channel and $\mathrm{Zn}(\mathrm{OH})^{+}$ species formed from a solid state reaction between dispersed $\mathrm{ZnO}$ and the proton in the zeolite. The preparation method has a significant influence on the distribution of the $\mathrm{Zn}$ species. The catalytic behavior of Zn-containing HZSM-5 in ethylene aromatization reaction showed that the aromatics selectivity was greatly enhanced with the introduction of $\mathrm{Zn}$, which resulted in a synergy effect between dehydrogenation species and Brönsted acid sites. $\mathrm{Zn}(\mathrm{OH})^{+}$species and $\mathrm{ZnO}$ species were responsible for aromatic formation from ethylene by acting as active sites for the dehydrogenation reaction. $\mathrm{ZnO}$ species were active for both dehydrogenation and hydrogenation and influenced the reaction mechanism by modulating the amount of Brönsted acid sites. The introduction of Zn into HZSM-5 zeolite in an optimal content is crucial for maximizing the aromatic selectivity.

\section{References}

[1] Liu H M, Li Y, Shen W J, Bao X H, Xu Y D. Catal Today, 2004, 93-95: 65

[2] Ai Sha N L H, Liu J X, He N, Guo H C. Chin J Catal (艾沙·努拉洪, 刘 家旭, 贺宁, 郭洪臣. 催化学报), 2013, 34: 1262

[3] Song Y Q Zhu X X, Xie S J, Wang Q X, Xu L Y. Catal Lett, 2004, 97: 31

[4] Song Y Q Zhu X X, Xu L Y. Catal Comm, 2006, 7: 218

[5] Choudhary V R, Panjala D, Banerjee S, Kinage A K. Microporous Mesoporous Mater, 2001, 47: 253

[6] Choudhary V R, Banerjee S, Panjala D. J Catal, 2002, 205: 398

[7] Yakovlev A L, Shubin A A, Zhidomirov G M, Van Santen R A. Catal Lett, 2000, 70: 175

[8] Lubango L M, Scurrell M S. Appl Catal A, 2002, 235: 265

\section{Graphical Abstract}

Chin. J. Catal., 2015, 36: 880-888 doi: 10.1016/S1872-2067(14)60289-8

Influence of Zn species in HZSM-5 on ethylene aromatization

Xuchuan Chen, Mei Dong*, Xianjun Niu, Kai Wang, Gang Chen, Weibin Fan*, Jianguo Wang, Zhangfeng Qin

Institute of Coal Chemistry, Chinese Academy of Sciences; University of Chinese Academy of Sciences
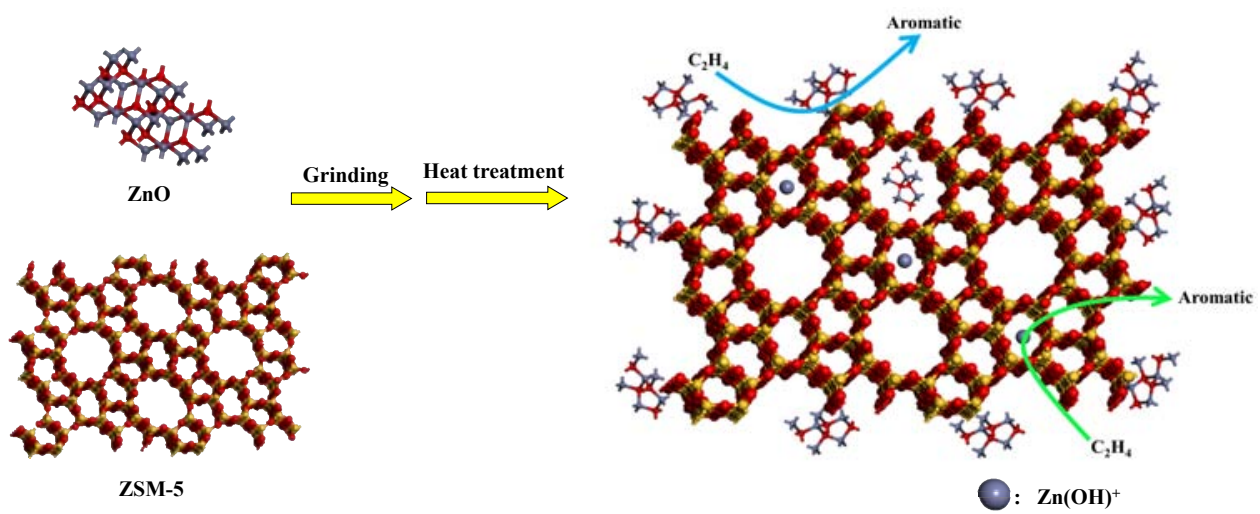

An efficient Zn-containing HZSM-5 catalyst for ethylene aromatization was prepared by physically mixing. Both $\mathrm{Zn}(\mathrm{OH})^{+}$and $\mathrm{ZnO}$ species facilitated the dehydrogenation of light alkanes, and promoted the formation of aromatics. 
[9] Yin S F, Lin J, Yu Z W. Chin J Catal (尹双凤, 林洁, 于中伟. 催化学 报), 2001, 22: 57

[10] Chen J, Zhang L, Kang H M, Ding F X. Chin J Catal (陈军, 张塗, 康慧 敏, 丁富新. 催化学报), 2001, 22: 229

[11] Ni Y M, Sun A M, Wu X L, Hu J L, Li T, Li G X.Chin J Chem Eng (倪友 明, 孙爱明, 吴小岭, 胡江林, 李涛, 李光兴. 中国化学工程学报), 2011, 19: 439

[12] Xin Y B, Qi P Y, Duan X P, Lin H Q Yuan Y Z. Catal Lett, 2013, 143: 798

[13] Chen J, Zhang L, Kang H M, Ding F X. Acta Petrol Sin (Petrol Process Section (陈军, 张錐, 康慧敏, 丁富新. 石油学报石油加工), 2000, 16(5): 8

[14] Berndt H, Lietz G, Vöiter J. Appl Catal A, 1996, 146: 365

[15] Kolyagin Y G, Ordomsky V V, Khimyak Y Z, Rebrov A I, Fajula F, Ivanova I I, J Catal, 2006, 238: 122

[16] Biscardi J A, Meitzner G D, Iglesia E. J Catal, 1998, 179: 192

[17] Yakerson V I, Vasina T V, Lafer L I, Sytnyk V P, Dykh G L, Mokhov A V, Bragin O V, Minachev K M. Catal Lett, 1989, 3: 339

[18] Li Q H, Mihailova B, Creaser D, Sterte J. Microporous Mesoporous Mater, 2000, 40: 53

[19] Maderia F F, Tayeb K B, Pinard L, Vezin H, Maury S, Cadran N. Appl
Catal A, 2012, 443-444: 171

[20] Ni Y M, Sun A M, Wu X L, Hai G L, Hu J L, Li T, Li G X. Microporous Mesoporous Mater, 2011, 143: 435

[21] El-Malki El-M, Van Santen R A, Sachtler W M H, J Phys Chem B, 1999, 103: 4611

[22] Kolyagin Y G, Ordomsky V V, Khimyak Y Z, Rebrov A I, Fajula F, Ivanova I I, J Catal, 2006, 238: 122

[23] Niu X J, Gao J, Miao Q, Dong M, Wang G F, Fan W B, Qin Z F, Wang J G. Microporous Mesoporous Mater, 2014, 197: 252

[24] Bordiga S, Lamberti C, Ricchiardi G, Regli L, Bonino F, Damin A, Lillerud K P, Bjorgen M, Zecchina A. Chem Commun, 2004, 20 : 2300

[25] Haase M, Weller H, Henglein A.J Phys Chem, 1988, 92: 482

[26] Liu J X, Ai Sha N L H, He N, Liu G D, Liang C C, Zhang X F, Guo H C. Chem Eng J, 2013, 218: 1

[27] Tholkappiyan R, Vishista K. Physical B, 2014, 448: 177

[28] Qiu P, Lunsford J H, Rosynek M P. Catal Lett, 1998, 52: 37

[29] Bi Y, Wang Y L, Chen X, Yu Z X, Xu L. Chin J Catal (毕怡, 王荣利, 陈 欣, 于政锡, 许否. 催化学报), 2014, 35: 1740

[30] Choudhary V R, Panjala D, Banerjee S. Appl Catal A, 2002, 231: 243

\title{
Zn物种对乙烯芳构化反应过程的影响
}

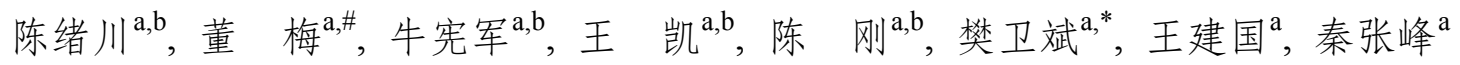 \\ ${ }^{\mathrm{a}}$ 中国科学院山西煤炭化学研究所煤转化国家重点实验室, 山西太原030001 \\ $\mathrm{b}$ 中国科学院大学, 北京 100049
}

摘要: 分别采用离子交换法和物理混合法制备了不同Zn含量的ZSM-5 分子篎催化剂, 采用X射线衍射、扫描电子显微镜、 $\mathrm{N}_{2}$ 物理 吸附、氨程序升温脱附、吡啶红外吸附光谱、紫外-可见光谱和X射线光电子能谱等技术研究了催化剂的结构、表面性质及 Zn 物 种种类, 探讨了 $\mathrm{Zn}$ 物种存在状态对乙烯芳构化反应的影响. 结果表明, 引入到 HZSM-5中的 $\mathrm{Zn}$ 物种包括三种状态, 即 ZnO晶体、存 在于分子笁孔道中的 $\mathrm{ZnO}$ 团簇以及 $\mathrm{Zn}$ 和分子笁质子酸中心通过固相反应生成的 $\mathrm{Zn}(\mathrm{OH})^{+}$物种; 不同的制备方法显著影响 $\mathrm{Zn}$ 物种 的分布. 比较了制备方法和Zn含量对ZSM-5分子笁催化剂在乙烯芳构化反应中性能的影响, 发现 $\mathrm{Zn}(\mathrm{OH})$ 物种是芳构化的主要活 性中心, 同时 $\mathrm{ZnO}$ 物种的存在有助于乙烯制芳烃反应的发生.

关键词: 乙烯; 芳构化; 锌物种; HZSM-5; 脱氢作用

收稿日期: 2014-11-27. 接受日期: 2015-01-09. 出版日期: 2015-06-20.

*通讯联系人. 电话: (0351)4199009; 传真: (0351)4041153; 电子信箱: fanwb@sxicc.ac.cn

通讯联系人. 电话: (0351)4046736; 传真: (0351)4041153; 电子信箱: mdong@sxicc.ac.cn

基金来源：国家重点基础研究发展规划(973计划, 2011CB201400); 国家自然科学基金(21273263, 21273264,21227002); 山西省自

然科学基金(2012011005-2, 2013021007-3).

本文的英文电子版由Elsevier出版社在ScienceDirect上出版(http://www.sciencedirect.com/science/journal/18722067). 